\title{
Republic or Constitutional Monarchy: the Political and Social Effects of Royal Visits to Australia
}

Meredith Comba

\begin{abstract}
Nineteenth century Australia achieved Federation on January $1^{\text {st }}$ after a half-century of discussion and debate between Federalists and Republicans. However, despite these ongoing political debates, Australia still greatly retained a strong sense of British identity due to immigration policies that only slowed in the 1880s. Focusing on the Australian publicô reactions to two Royal Tours, in 1867 and 1901, this paper attempts to address why a Commonwealth model of Federation was created in 1901 as well as to more fully understand how significantly Australian cultural identity and support of the monarchy as a symbol of the British Empire contributed to the nineteenth century political scene.
\end{abstract}

Australian Federation on January $1^{\text {st }}, 1901$ was the culmination of half a centuryôs worth of discussion on the political fate of the Australian colonies. Federalists called for the creation of a united Australia with increased control over domestic affairs while still remaining a constitutional monarchy. At the same time a small Republican undercurrent argued for more political separation from Great Britain. Republicans on the whole condemned the monarchy as both a link with Great Britain as well as a symbol of all that was superfluous and excessive in nature. ${ }^{1}$ To Republicans, the monarchy was the perfect symbol for the political sterility of the Australian colonies in the nineteenth century as well as one of the barriers that prevented Australian political advancement. However Republican arguments were not the mainstream ideology and a majority of Australians in the second half of the nineteenth century maintained a close cultural tie to British culture and the symbol of the monarchy in particular. Royal tours, such as the ones occurring in 1867 and 1901, are valuable examples and are indicative of the cultural and political values of nineteenth-century Australians. How everyday Australians viewed the monarchy and reacted to official visits is a vital opportunity to understand how the development of Australian cultural and political identities advanced in the nineteenth century. What is clear through examining the royal tours of 1867 and 1901 in the context of the slowmoving Federation movement is that even with Federation in 1901 the Australian national identity was still intrinsically tied to British culture, the monarchy, and the Empire that Republicanism was generally distained. Instead the Royal Tour of 1867 paired with large-scale British immigration made it impossible for the Australian colonies to ever consider the creation of a Republic and full political separation from Great Britain. Federation only was achieved when the population of the Australian colonies began to be majorly locally born, but even then the cultural bond between Britain and Australia was still too strong to break.

Although Republicanism was a small political undercurrent in the late nineteenth century, there is one example of Republicanism that is especially prevalent in the memory of Australians: the Eureka Stockade. This December 1854 Rebellion was led by a group of disgruntled gold miners, the Ballarat Reform League, who, inspired by the many stories of the American revolution from American miners in their midst, opposed paying Miners Taxations and Miners Licences without

\footnotetext{
${ }^{1}$ Mark McKenna, The Captive Republic: A History of Republicanism in Australia 1788-1996 (Cambridge: Cambridge University Press, 1996), 114.
} 
receiving any political representation. ${ }^{2}$ It was a small-scale rebellion against British colonial authority after the newly appointed Governor of Victoria, Sir Charles Hotham, implemented a strict enforcement of registering all gold miners. ${ }^{3}$ Although the rebellion was incredibly shortlived, many historians argue that the Eureka Stockade was the moment in which the Australian colonies first took notice of their developing national identity. ${ }^{4}$ This view maintains that the Gold Rush and the Eureka Stockade were the sparks that led to the colonies developing rapidly into modern societies that called for political unity. Yet, the idea that the rough-and-tumble Australian identity or ñmateshipò and unaffected good-naturedness developed when a group of disgruntled gold miners at Ballarat declared a short-lived and completely unsuccessful Republic is a nationalist myth. ${ }^{5}$

When the Ballarat Reform League set up their barricades their act of defiance was not a plucky thumbing of their noses to authority and the British ñpommies,ò but rather a hope to achieve reform. Their barricades were their symbolic objection to paying Miners Taxations and Miners Licenses without receiving any political representation. ${ }^{6}$ They hoped to reform political representation and the police system, not to establish a Republican movement in the twenty-first century sense. The Eureka Rebellion contained radical ideologies, but considering that the Eureka Stockade was established by the Ballarat Reform League, the idea of Republicanism as a true political goal was unlikely. An organisation which uses the word ñReformò in its name can hardly be taken seriously as a true challenge to the status quo. Rather, the rebels at Ballarat were merely dissatisfied with the political organisation of the Australian colonies, not necessarily their position within the Empire and under the monarchy. Establishing a Republic was a dramatic way to draw notice to their call for political changes, but in longevity, the Republican movement that they began almost completely disappeared until the 1880s and 1890s. Due to the small scale of the movement as well as the significantly rural location of the rebellion, launching a long-lasting and widespread revolution would have been incredibly difficult.

Furthermore, the similarities between the arguments made by the Eureka rebels and other groupsôdemands for greater representation makes it difficult to truly see the movement as a representation of Australian identity. The Eureka rebels may have declared a Republic but their short-lived movement hardly represented the majority views of Australians living in the colonies. Their rebellion ended in a bloody skirmish on $3^{\text {rd }}$ of December, 1854, that killed at least twentyseven rebels and wounded several more. ${ }^{7}$ This violent and dramatic end ensured that the Eureka Rebellion was followed by two decades of rather feeble Republican political movements. ${ }^{8}$ With significant portions of the population of the Australian colonies being British-born it is hardly surprising that the idea of Republicanism still carried about it the taint of the French Revolution. The chilling memory of French Republicanism, streets of blood, and the decades of war that

\footnotetext{
${ }^{2}$ Norman Bartlett, The Gold Seekers: The story of the Australian Gold Rush (London: Jarrolds Publishers, 1965), 188.

${ }^{3}$ Jay Monaghan, Australians and the Gold Rush: California and Down Under, 1849-1854 (Berkeley: University of California Press, 1966), 241.

${ }^{4}$ Russell Ward, ñDiggers, Democracy and Urbanisation c.1851-85,ò in Australia since the coming of man (New York: St. Martinô, 1987), 102.

${ }^{5}$ Ward, Diggers, 102.

${ }^{6}$ Bartlett, The Gold Seekers, 188.

${ }^{7}$ Ibid., 213.

${ }^{8}$ McKenna, Captive Republic, 109.
} 
followed would still have played a significant role in the political consciousness of Australians in the mid-nineteenth century in the same way it weighed heavily upon European politics.

Republicanism was less preferable to monarchies and democracies with limited suffrage. The dramatic bloodshed of the Eureka Stockade could only have reinforced the idea that

Republicanism, radicalism, and rebellion were always accompanied by horror and devastation.

Indeed, in 1854 there was little admiration for the Eureka Rebels; the press had called the Eureka

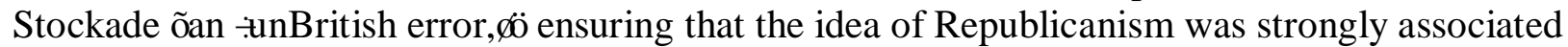
with the idea of cultural distinction from the mother country. ${ }^{9}$ Those who supported the idea of an independent and free Australia did see the Rebellion as an unhappy tragedy, but on the whole the rebels were seen as criminals acting against the Queen. ${ }^{10}$ Despite this, Republicanism did survive the Eureka Stockade. However, it is clear when examining the Republicanism of the 1850 s and 1860 s that while radical for the time period, in modern terms, nineteenth-century Republicanism had surprisingly moderate political goals. Republicans such as David Blair and John Dunmore Lang aimed for the creation of a United Australian Republic but separation from the monarchy and Empire was a different discussion all together. As Blair stated in his newspaper, The Argus, Republicanism was ñcompatible with continued allegiance to the Crown. ${ }^{11}$ Lang shared a similar view. ${ }^{12}$ Republicanism in the 1850 s and 1860 s was therefore dissimilar to the traditional definition of Republicanism. Whether it was found in the hearts of working-class gold miners or middle-class intellectual like Blair and Lang, Republican efforts sought to reform the political sphere of Australian life, but had no desire to alter Australian culture and identity much in the same way as Federation. While a highly unpopular and radical

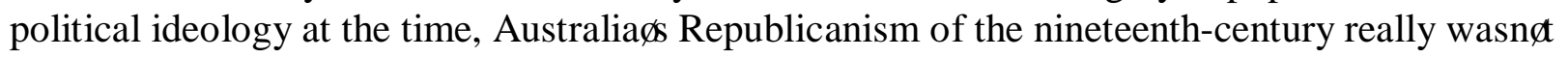
the antithesis of Federalism, rather they shared many common goals of reform. Australian republicans remained ñoyal to the British Crown, but not to British absolutism. ${ }^{13}$

Even with the similarities of Republicanism and Federalism, the bloodshed at the Eureka Stockade created two decades of stunted Republicanism while in contrast Federalism in the 1850s and 1860s had already begun to take shape under the guidance of Henry Parkes. ${ }^{14}$ While Parkesôinfluence to Federalism was most significant in the 1880s, in the 1850s he had already begun to speak publically on the subject and to publish in newspapers. ${ }^{15}$ However, despite Federalism being a more mainstream political ideology, the call to unite the colonies was weak as many saw Federation unnecessary as each colony gained more political control over their domestic affairs. The granting of new Constitutions in Victoria, New South Wales, South Australia, and Tasmania in 1855 allowed for limited self-government greatly decreasing the support for both Federation and Republicanism. ${ }^{16}$ The newfound control over domestic politics pared with economic boom of the gold rush that lasted for three decades, the desire for largescale political change withered away. ${ }^{17}$ However, in the late 1860 s one event retarded the growth

\footnotetext{
${ }^{9}$ McKenna, Captive Republic, 102.

${ }^{10}$ Ibid, 102-103.

${ }^{11}$ Ibid, 106.

12 Ibid.

${ }_{13}$ Age, 24 May 1855, in McKenna, Captive Republic, 107.

${ }^{14}$ McKenna, Captive Republic, 109.

15 Ward, Diggers, 197.

${ }^{16}$ McKenna, Captive Republic, 107.

${ }^{17}$ Ibid, 109.
} 
of Federalism and Republicanism more significantly that any of the economic or political changes of the 1850 s.

Considering the ardent Republicanism debates of the 1990s it is difficult to imagine that the British Monarchy was beloved by earlier Australian generations. Yet, the inherent symbolism and allure of royals and the monarchy was extremely effective at strengthening the cultural bonds between Britain and the Australian colonies as well as almost halting the development of Republicanism, Federalism, and nationalistic movements in nineteenth-century Australia. More specifically, there was one specific moment in the history of Australia that accomplished the affirmation of British culture and identity in Australia: the Royal Tour of 1867. Or as Mark McKenna calls it in his book, The Captive Republic, ñA Loyalty Play. ${ }^{18}$ This royal tour carried out by Queen Victoriaôs second-eldest son, Prince Alfred, Duke of Edinburgh, was deliberately planned to spread Imperial good will and represent the monarchy abroad. ${ }^{19}$ Like all royal tours and public functions of the modern British royal family, the 1867 royal tour was purposefully planned with one goal in mind: to portray the monarchy as the benevolent and compassionate mother of all the colonies. Even the year that was chosen for Prince Alfredôs tour was purposeful: the year in which one of the Empireâs largest colonies assumed domestic independence. $^{20}$

In 1867 with Canadian Confederation, the Monarchy realised that if they had granted considerable freedom to one of their colonial children that it was also necessary to spread Imperial good will amongst their others. After the Indian Mutiny in 1857 Britain grew ñncreasingly sensitive to the need to promote its reputation as a beneficent ruler of subject peoples, a supportive mother of its booming settler colonies, and a government responsive to ordinary Britons..$^{21}$ Their new monarchical policy was aimed at reinforcing the ties between coloniser and the colonies, without any appearance of favouritism. Alfredôs tour was, in a way, the first opportunity for a member of the royal family to begin cultivating the new monarchical policy and luckily for him the tour was carried out beautifully. In fact, Alfredôs tour paired with the continual numbers of British immigrants swelling the populations of the Australian colonies is a significant factor in delaying both Federalist and Republican political advances. From the moment Prince Alfred arrived in Australia on October $31^{\text {st }}, 1867$ until he left in April 1868, Alfred was an extension of his mother, the Queen, and a symbol of what it was to be British. His naval career made him an even better harbinger of Empire. Alfredôs casual approachability, seafaring lifestyle, and, most importantly, his strength in the face of adversity earned him and the monarchy lasting popularity in Australia.

During the nineteenth century the British monarchy, no longer having even a cursory political role, began to instead invent or create a purpose and an image for themselves. ${ }^{22}$ They were

\footnotetext{
${ }^{18}$ Ibid, 112.

${ }^{19}$ Later also the Duke of Saxe-Coburg-Gotha.

${ }^{20}$ Canadian Confederation was passed on July $1^{\text {st }}, 1867$ after receiving royal assent on March $26^{\text {th }}, 1867$ with the British North America Act.

${ }^{21}$ Cindy McCreery, ñTelling the Story: HMS Galateaôs Voyage to South Africa, 1867,ò South African Historical Journal 61, no. 4 (2009): 819

${ }_{22}$ David Cannadine, ñThe Context, Performance and Meaning of Ritual: The British Monarchy and the đ́nvention of Traditionô 1820-1977,òin The Invention of Tradition, ed. Eric Hobsbawm and Terence Ranger (Cambridge: Cambridge University Press, 1983), 108.
} 
forced to adapt and assume a more symbolic role. The monarchy especially transformed itself during the reign of Queen Victoria and with the improvement of naval technology it was now possible to undertake the royal good-will tour, of which Prince Alfred was the pioneer. In his case, propagating the image of a single Empire united at the motherly bosom of Queen Victoria was quite easily achieved. When Alfred arrived in ñthe port of Glenelg near Adelaide,ò on the $30^{\text {th }}$ of October 1867, massive groups exuberantly cheered him on and the next day was declared a public holiday in celebration. ${ }^{23}$ In the following months as Alfred visited the port cities of Adelaide, Melbourne, Sydney, and Brisbane, he attended concerts, picnics, military reviews, and banquets. ${ }^{24}$ These ceremonial duties were the mediums in which the monarchy revised their role in the Empire, placing Alfred on public display to increase the audience to the splendour and romance of royalty. As Prince Alfred traveled he was almost unanimously acclaimed, and one editor of the Adelaide Observer even requested that when a Federal Union of Australia was created that Alfred should be their sovereign. ${ }^{25}$ All public occasions were opportunities for Alfred to reinforce Imperial loyalty and cultural ties, and his popularity demonstrates how successfully he carried out the symbolic, ceremonial role of the monarchy.

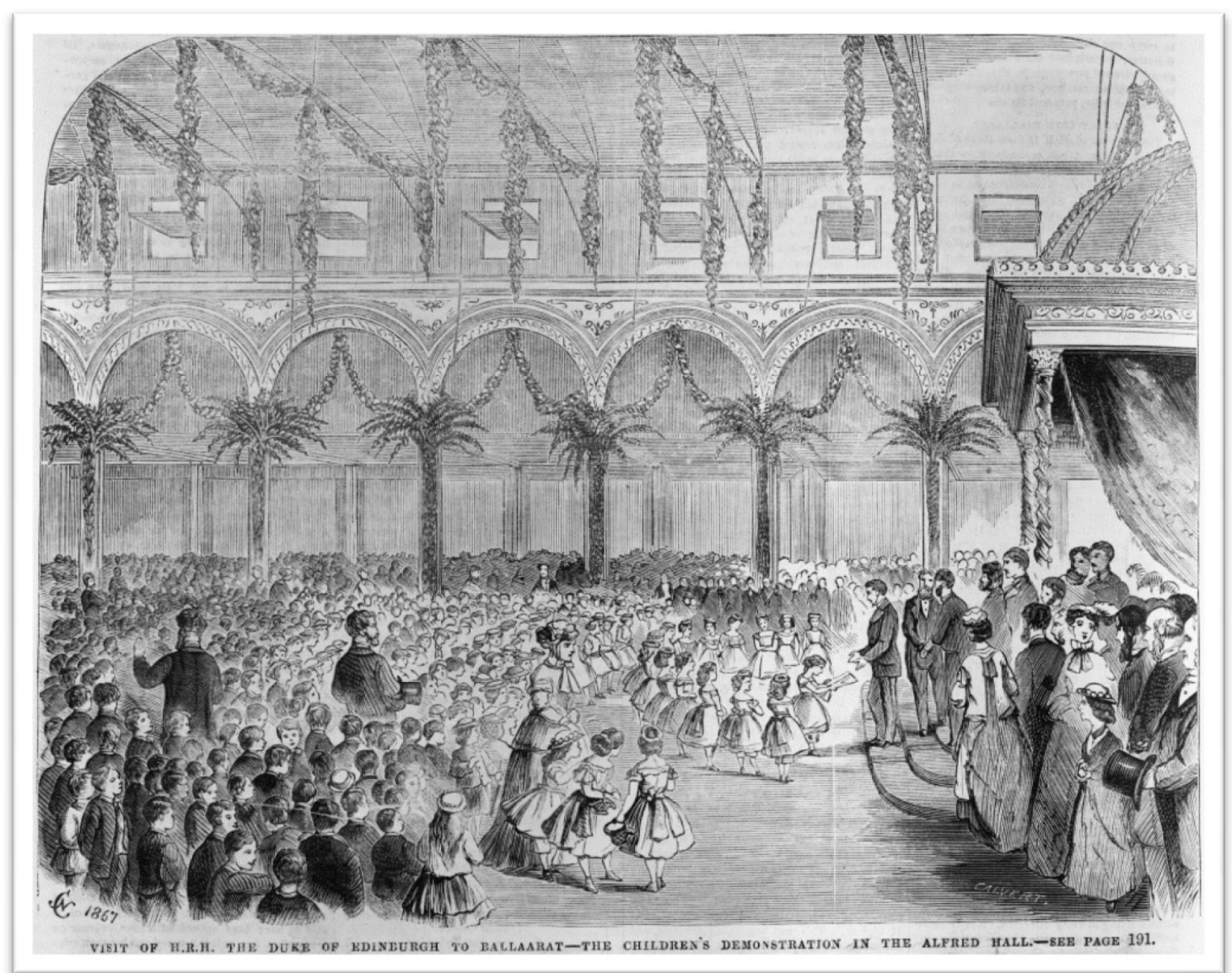

Image 1. Samuel Calvert. ñVisit of H.R.H. The Duke of Edinburgh to Ballaarat ï the Childrenô Demonstration in the Alfred Hallò (December 27 ${ }^{\text {th }}$, 1867). Illustrated Melbourne Post.

${ }^{23}$ Bee Jourdan and John Van Der Kiste, Dearest Affie...: Alfred, Duke of Edinburgh, Queen Victoria's second son, 1844-1900 (Gloucester: Alan Sutton Publishing Limited, 1984), 60.

${ }^{24}$ Ibid., 60.

${ }^{25}$ Mark McKenna, ñMonarchy: From Reverence to Indifference, ò in Australia's Empire, ed. Deryck M. Schreuder and Stuart Ward (Oxford: Oxford University Press, 2008), 269. 
The entirety of Prince Alfredô royal trip was not smooth sailing. On March $12^{\text {th }}, 1868$ while just outside Sydney at a picnic luncheon, an Irishman, Henry James OôFarrell, attempted to assassinate the young prince. ${ }^{26}$ Aiming at Prince Alfredôs back, Ođ̛́arrellôs shot was luckily deflected and instead of severing the Princeôs spine the bullet lodged itself in the Alfredô abdomen. The assassination attempt caused pandemonium, and onlookers not realising that the wound was not fatal descended upon Oôfarrell in rage. Oôfarrell was beaten bloody and immediately arrested while Alfred was transported back to Government House where it was deduced that his heavy leather suspenders had stopped the bulletsôtrajectory into the spine. Although suffering from blood loss, Prince Alfred made a speedy recovery, returning to the spotlight on April $3^{\text {rd }} 27$

The assassination attempt cannot be made light of, but there is no doubt that in the case of Prince Alfred, the attempted assassination was a wonderful opportunity for increasing Imperial ties between mother country and colony. Overwhelming public outrage made it a fantastic media opportunity to continue to market the romantic and gilded symbolism of the monarchy. The assassination was a shock, but many Australians also considered it as an embarrassment. They could not believe that any ñtrueò Australian would attempt such an inhospitable, dishonest, and treasonous action against Britain and the Crown. The general outrage even contains echoes of the popular distain for Republicanism and Fenianism. The fact that Ođ̊Farrell was Irish-Catholic was not lost upon the Australian public; Henry Parkes argued that Ođ̊Farrellôs attempt to kill the Prince was in fact a Fenian conspiracy. ${ }^{28}$ It was an easy story to sell as Alfredô brush with death had all the makings of a romantic, heroic story. At the centre of this melodrama there was r̃[an] unfortunate wretch who had so vilely outraged the rites of hospitalityò and a handsome Prince. ${ }^{29}$ Prince Alfred, being young and moderately good looking, could easily be cast as the hero in a dramatic tale in which the monarchy was wrongly attacked by a foe who conveniently was Irish, Roman Catholic, and unhinged. Alfred, as ñthe sailor princeò who had charmed officials with his affable nature quickly became even more widely admired and beloved. As John Van Der Kiste and Bee Jourdan aptly put it, ñthere is ample proof that nothing boosted loyalty to the crown so much as an attempt on a royal life. o $^{30}$

That such a violent attack could be taken against a guest created so much righteous indignation that even after Ođ̊Farrell was arrested and it was clear that the Princế injury was less traumatic than originally feared, the Australian colonies widely celebrated Alfredô lucky escape from death and were just as swift to condemn those who were seen as anti-monarchists. Celebrations of thanksgiving were held on Sunday March $22^{\text {nd }}$ to rejoice the Prince $\hat{Q}$ survival. ${ }^{31}$ A bystander at the picnic who had grabbed OôFarrell preventing a second shot being fired received a gold watch in a public display of gratitude from the young Duke of Edinburgh. ${ }^{32}$ OâFarrell in the meantime was not treated lightly. It is interesting to consider that on the occasion that assassination attempts were made against Queen Victoria; five of her seven would-be assassins

\footnotetext{
${ }^{26}$ Jourdan and Van Der Kiste, 66.

27 Ibid, 67.

${ }^{28}$ McKenna, Captive Republic, 112.

${ }^{29}$ ñThe Trial of Henry James OâFarrell for the Attempted Murder of His Royal Highness Alfred Ernest Albert, Duke of Edinburgh,òSydney: Illustrated Sydney News, 20 April 1868. Trove: http://trove.nla.gov.au/version/31304072

${ }^{30}$ Jourdan and Van Der Kiste, 67.

31 Ibid.

32 Ibid.
} 
were pardoned of the death sentence and were sent to Australia to serve their time. ${ }^{33}$ However, in the colonial setting, the reaction to Ođ̊Farrellôs treason was significantly harsher. Considering that many Australians at the time were descended from convict ancestors, their lack of sympathy is interesting, but it seems that the colonies were whole-heartedly demonstrating their loyalty to the crown. The day following the assassination attempt, the Sydney Herald stressed that OâFarrellôs actions had ñno connection in any way whatsoever, however remote, with anything Australian..$^{34}$ Irish immigrants grew unpopular as OâFarrell was charged with Feninan sympathies and only six days after the assassination attempt the New South Wales government began enacting measures to ensure harsh treatment of criminals like Oôfarrell. The Treason Felony Act, was legislated only six short days after Ođ̊Farrellôs attempt on the Princeố life, on March $18^{\text {th }}$, to guarantee ñthe better security of the Crown, ò and allowed for extreme suppression and punishment of crimes that were deemed treasonous. ${ }^{35}$

Similar laws were passed in New South Wales outlawing any public speech or publication that contained criticism of the Queen or monarchy limiting the growth of anti-monarchical ideologies by limiting their ability to publically attract followers. ${ }^{36}$ These laws not only demonstrate how intensely Australians supported the monarchy at the time but also how far they would go to demonstrate their loyalty to ñqueen and country.ò Whether OôFarrell was a Fenian who had acted on political motives or was a man with unstable mental faculties hardly mattered, rather it was more important that the dramatic and inflammatory moment was dealt with harshly to demonstrate the loyalty of the Australian colonies to Great Britain. Ođ̂Farrellôs attack of the Prince could be easily portrayed as anti-monarchical in order to reaffirm the Australian coloniesô Imperial convictions and to denigrate republicans as ñso far outside the acceptable boundaries of the political spectrum that they had become potential criminals..$^{37}$

The lasting monarchism generated from Alfredôs visit paired with the economic prosperity of the mid-century lasted until the 1880s, when the Federation movement dramatically increased. Historians have always debated what contributed to the shift from ardent Imperialism to Federalism some arguing about racial tensions, economic fears, and countless other social and political factors. ${ }^{38}$ Although tensions and fears, such as the fear of Asian invasion from the north, did significantly contribute to the Federation discussions, without the changes in immigration and population make-up that occurred in the last decades of the nineteenth century Federation would not have been considered as a solution to societyô dilemmas. It is hard to imagine that anyone would have rallied behind the popular slogan, ñAustralia for Australians, ò in the 1860s and 1870s when immigration from the British Isles was at its peak and the Australian colonies were still intrinsically tied to Britain culturally. However, by the end of the century that had begun to change. In the 1820 s immigration schemes steadily supplied the Australian colonies with large numbers of immigrants from the British Isles and the majority of the Australian

\footnotetext{
${ }^{33}$ Paul Thomas Murphy, Shooting Victoria: Madness, Mayhem, and the Rebirth of the British Monarchy (New York: Pegasus Books, 2012), x.

${ }^{34}$ Sydney Morning Herald, 16 March 1868, in McKenna, Captive Republic, 112.

${ }^{35}$ Sydney Morning Herald, 19 March 1868, in McKenna, Captive Republic, 113.

${ }^{36}$ McKenna, Captive Republic, 113.

37 Ibid.

${ }^{38}$ David Day, ñ̃̂̃The Time for union is Comeòò, in Claiming a Continent: A New History of Australia (Sydney and London: HarperCollins, 1997), 201-203.
} 
population had immigrated to the colonies. ${ }^{39}$ Despite the bad reputation of the Australian colonies as morally corrupt due to the convict populations, by the 1840s Australian immigration slowly blossomed due to government and private immigration schemes, such as Christine Chrisholmô ñThe Family Colonization Loan Society (FCLS)ò which was established in 1849. ${ }^{40}$ Other factors also significantly increased the numbers of immigrants in the mid-century. With the transportation of convicts beginning to end in 1840 and the economic boom caused by the gold rush in 1853 the Australian colonies began to be seen as the beacon of hope rather than the immoral playgrounds of criminals. ${ }^{41}$ Lastly, with the quality of passenger ships being improved with the Passenger Act of 1855 immigration reached an all-time high. ${ }^{42}$

More and more people began to seek their fortunes in Australia, and by the end of the nineteenth century, 1.6 million people had immigrated to the Australian colonies from Great Britain. ${ }^{43}$ These immigrant colonies made up of individuals and families that were seeking to improve their lot in life through mining, farming, or owing a business were the audience for Prince Alfredôs tour in 1867. It is impossible to say of course that all immigrants who arrived in the colonies were ardent monarchists, but due to the significant immigrant component of the populations the Australian colonies were more culturally similar to Britain than they were at later times. They showed loyalty and support to the monarchy because the monarchy was a symbol of what it meant to be British and what it meant to be part of an Empire. They would have shown great pride in their colonies being acknowledged as important enough to merit a visit, and therefore would have also been furious that an attempt on the Princeôs life was dared. The populations of the Australian colonies were made of large numbers of people who had only shortly arrived in the colonies themselves, making it unlikely that any identity preceded their British and Imperial sentiments. As we have also seen, any radical position such as Republicanism was not the norm, so it is therefore hardly surprising that the Australian colonies in the mid-century remained ñ[a] new Britannia in another world. $0^{44}$ It is also not surprising that the romantic and dramatic royal tour of Prince Alfred in 1867 helped to reinforce the Imperial loyalties that were already present.

However as the nineteenth century grew to a close immigration began to decrease and the numbers of native-born white Australians began to increase. By 1891 Australiaôs population had clearly shifted from being maintained by immigration to being a self-sustaining population. There were 2.17 million native-born Australians while there were 830,000 individuals who had been born in the British Isles. ${ }^{45}$ By 1901 the numbers had become even more dramatic with 2.9 million locally born Australians and 685,000 immigrants. ${ }^{46}$ Of course, these numbers do not include minority groups like Chinese labourers or Aboriginal peoples; however, they still demonstrate the make-up of the individuals who had political influence at the time. Therefore,

\footnotetext{
${ }^{39}$ Eric Richards, ñHow Did Poor People Emigrate from the British Isles to Australia in the Nineteenth Century,ò Journal of British Studies 32, no. 2 (July 1993), 250.

${ }^{40}$ Kristine Kelly, ñSpeaking Up: Caroline Chrisholmôs Rhetoric of Emigration Reform,ò Nineteenth Century Studies 23 (May 2009), 18.

${ }^{41}$ Ibid, 18 \& 32.

42 Ibid, 32.

${ }^{43}$ Ibid.

${ }^{44}$ William Charles Wentworth, Australasia (1823), in Russell Ward, ñDiggers, Democracy and Urbanisation c. 1851-85,òin Australia since the coming of man (New York: St. Martinôs, 1987), 199.

${ }^{45}$ Ged Martin, Australia New Zealand and Federation, 1883-1901(London: Menzies Centre for Australian Studies, Kingôs College London, 2001), 34.

${ }^{46}$ Martin, Australasia, 34.
} 
these statistics demonstrate the individuals that had a hand in achieving Federation. The population was also quite young. In 18911.5 million of Australiâि population were under the age of twenty, and by 1901 the number had risen to 1.7 million. ${ }^{47}$ While this does include quite young children, it cannot be ignored that large numbers of the 1.5 million individuals in 1891 would have achieved majority by 1901, making the number of voters increasingly youthful. It is hardly surprising then that this increasingly youthful population of Australian-born voters were less enchanted with Britishness, the monarchy, and the idea of Empire. Rather, like the Baby Boomer generation in the twentieth century, the political atmosphere in Australia was heavily influenced by young voters who were interested in shifting away from the conservative support of the Empire to a gradual movement towards a unified Australia. They still had strong ties cultural ties to Britain and Empire, but their desires for political separation and distinction were stronger.

In the 1880s Federation was accelerated and the catchphrase, ñAustralia for the Australians, Ò and membership in the Australian Native Association (ANA) became popular. ${ }^{48}$ The simple existence of such slogans and societies is demonstration that there was a growing sense of division between what it meant to be British and what it meant to be Australian. In the historian Mark McKenna@̂ words, ñthere was no surer sign that the relationship between the colonies and Britain was undergoing a process of redefinition than the formation of the Imperial Federation League in London in $1884.0^{49}$ These organisations were not the short-lived rebels of the Gold Rush and the Eureka Stockade. Rather, they attempted to achieve greater political control over their domestic affairs using legal means to increase their influence. Some still hoped for a Republic, but the nature of Republicanism in the late nineteenth century barely resembled the reforming movements of the 1850s that still wanted to maintain the monarchy and the Empire. Federation was not a fast-moving political movement, despite the fact it did speed up in the 1880s, and Republicans frustrated by the slow speed of Australian Federation began using the monarchy as an easy target to vent their frustrations. To the Republican faction, ñThe Royal family exists to play baccarat and lay foundation stones, and to make dreary speeches at dreary institutesé to yawn vacuously over addresses from bumpkin corporations and to be fat and stupid and unutterably dreary..$^{50}$

Although Republicanism began to become more radical, it does not mean that it was the majority view in the colonies. In fact, there were many incentives to remain within the Empire. Seventy percent of Australiaôs imports were from Great Britain and eighty percent of Australian exports reached London, facts that were not lost upon the Federalists. ${ }^{51}$ The Federalists knew that the Empire, and the monarchy as a symbol of Empire, were beneficial and remained loyal to both even as the Federation movement advanced. Many factors contributed to the advancement of Federalism and the increase of referendums, conferences, and discussion throughout the last decades of the nineteenth century. The racism that would later solidify in the White Australia Policy, increased focus on defense, the economic slump of the 1890s, and the worst drought of modern history. ${ }^{52}$ There were also increases in communication and transportation between the

\footnotetext{
47 Ibid, 34.

${ }^{48}$ McKenna, Captive Republic, 124.

${ }^{49}$ Ibid, 125.

${ }^{50}$ Bulletin 16 January 1892, in McKenna, Captive Republic, 134.

${ }^{51}$ McKenna, Captive Republic, 125.

52 Ibid, 32, 43, 48. The drought lasted from 1895 to 1903.
} 
colonies. ${ }^{53}$ Populations made up of young, native-born white Australians, desperate to improve the economy of the colonies had both the reasons and the tools to begin increasing Federalist discussions, seeing Federation as a better solution for their problems than falling back upon Imperial aid and solutions. The mere fact that groups like the Australian National Union desires to ñstimulate a national patriotic feeling amongst Australians of all classes and creedsò demonstrates that the populations in the Australian colonies were finally ready to overlook their long-standing competition and rather discuss the possibility of them creating their own nation that was not politically reliant upon the mother country or the Empire. ${ }^{54}$

At the same time, the Australian colonies remained inherently British, even with the achievement of Federation. As Russell Ward argues, ñAustralia remained basically a remote, provincial British society..$^{55}$ Federation in the late nineteenth century took two decades to achieve because of constant disagreements between the various colonies. For example, the 1898 Federation bill failed to be passed as Queensland and Western Australia failed to participate and there was a lack of a majority vote in New South Wales. ${ }^{56}$ These failed referendums often drew colonies apart and significantly stunted the Federation movementô progress, heightening the distrust between colonies and in many ways reaffirming the Empire. Ultimately the increasing political desire for Federation superseded the differences between the colonies, but by no means did it eliminate the fact that the colonies felt more culturally connected with the Empire than with each other. The strong cultural ties to Britain remained and can be easily seen in the manner in which Australia, even after Federation in 1901, greeted the monarchy. In fact, the support of the monarchy had changed little over the course of the Federation movement and what little impotent Republicanism remained almost evaporated overnight when the heir to the throne, Prince George and his wife, Princess Mary reached the new Commonwealth of Australia. ${ }^{57}$ Their Australian leg of their 231-day good-will trip to Australia, New Zealand, and Canada occurred on a symbolic year, much the same way as Alfredôs 1867 tour. ${ }^{58} 1901$ was not only chosen to how the benevolent monarchyôs support behind Australian Federation, but the trip was also marked the first year of the reign of Edward VII. To reinforce the monarchy as the benevolent leaders in a strong and beneficial British Empire was also important in the light of the role of Britain in the Boer War.

Prince George, later George V, had had a naval career in his youth as his brusque, sea-faring manner and unaffected charm were publically acclaimed in Australia in the other colonies. ${ }^{59}$ In fact there are striking similarities between the characters of Prince Alfred and Prince George, both of whom were beloved by colonial populations for their unstuffy attitude. Prince George and Princess Mary arrived in Australia to spread Imperial cheer, but their primary role was to officially open the Australian Parliament in the place of his father, King Edward VII. This opening was attended by thousands of cheering people who sang and danced in the streets, celebrating the birth of a federated Australia, but also the young Prince and Princess. Of course,

\footnotetext{
${ }_{53}^{53}$ McKenna, Captive Republic, 50.

${ }^{54}$ Advertiser, 4 July 1887, in McKenna, Captive Republic, 153.

${ }^{55}$ Ward, Diggers, 117.

${ }^{56}$ Martin, Australasia, 25.

${ }^{57}$ At this time they had not been crowned as Prince and Princess of Wales, but were rather, still titled as Duke and Duchess of York.

${ }^{58}$ Andrew Roberts, ñGeorge Vò in The Lives of the Kings \& Queens of England, ed. Antonia Fraser (London: Seven Dials, 1999), 333.

${ }^{59}$ John Gore, King George V: A Personal Memoir (London: Allermarle Library, 1949), 49.
} 
it could be argued that the cheering crowds only turned out for the opening of parliament and were uninterested in the royals; yet, the royal couple were significantly praised and admired for their own merits. It is clear in the effervescent levels of excitement of Australians wherever the royal couple went that Prince George and Princess Mary were very well liked, whether they were reviewing troops, displays of Aboriginal warfare, or attending countless other public functions. ${ }^{60}$ In fact, the royalsôrole in the celebration of Federation was cheered with booming guns, the singing of Rule Britannia, and ñthunderous [roars] of cheering,ò in moments that ñfanned [Australiaôs loyalty to the Empire] to a white heat. $0^{61}$ There is every indication that the symbolic romance and charms of the monarchy still held considerable sway upon Australian hearts and minds in 1901 despite Federation. Therefore, if large numbers publically praised the monarchy and demonstrated their loyal support in cheers and public events, they also were cheering on the Empire and what it was to British. In 1901 there was no definitive and convenient media opportunity to demonstrate the public support, as there had been in 1867 with the attempted assassination of Prince Alfred, but the widespread success of the 1901 tour is good proof of the cultural identity of late-nineteenth century Australians. Australia was a newborn nation that had been for decades squabbling colonies predominately made-up of immigrants from the British Isles. They may have called for greater controls over the political lives, but even with the increase of Federalism and Republicanism in the late nineteenth century it is clear from even the briefest amount of information on the 1901 tour is that the long-lasting cultural impacts of immigration and the royal tour of 1867 still maintained strong cultural connections between Britain and Australia.

When examining the cultural and political ideologies of Australians it is clear that there was a shift in the way Australians felt about their political lives. Federalism and Republicanism did shrink and grow according to the cultural feeling of Australians, ultimately being successful at achieving the creation of an Australian Commonwealth in 1901. On the other hand it is interesting to see that while the political movements that lead to Federation in 1901 did significantly change in the late nineteenth century that the cultural identity of the Australian colonies did not alter nearly as quickly. Studying the public reactions to the two official royal tours of 1867 and 1901, it is clear that even though the cultural identity had changed with the decrease in immigration and the increase in the native-born Australian populations, Australia in 1901 was still intrinsically tied to the monarchy and the Empire. In some ways there were both considerable and limited amounts of change. Politically, Australia became a unified

Commonwealth, finally resolving the long-standing question of how the continent of Australia would be governed. In contrast, it is striking to see that while there were considerable advances and changes in the political identity of Australia in the nineteenth century, the manner in which Australians identified themselves culturally had not changed as dramatically. However by the latter half of the nineteenth century, largely due to the long-lasting, dramatic, and over-whelming popular royal tour of 1867 in tandem with the large scale British immigration to the Australian colonies that lasted until the 1880s, the cultural ties between Australians and British culture were too great.

\footnotetext{
${ }^{60}$ Sir Philip Gibbs, George the Faithful: The Life and Times of George V "The People's King," 1865-1936 (London: Hutchison \& Co. Ltd., 1936), 110-115.

${ }^{61}$ Ibid., 110-115.
} 


\section{Bibliography}

Bartlett, Norman. The Gold Seekers: The Story of the Australian Gold Rush. London: Jarrolds Publishers Ltd., 1965.

Calvert, Samuel. ñVisit of H.R.H. The Duke of Edinburgh Ballaarat $̈$ ï the Childrenô Demonstration in the Alfred Hall.òEngraving Melbourne: Robert Stewart, December 27, 1867. Illustrated Melbourne Post. http://search.slv.vic.gov.au/primo_library/libweb/action/dlDisplay.do?docId=SLV_VOY AGER1652587\&vid=MAIN (accessed February $23^{\text {rd }}, 2014$ ).

Cannadine, David. ñThe Context, Performance and Meaning of Ritual the British Monarchy and the đ́nvention of Traditionô c. 1820-1977. ò In The Invention of Tradition, edited by Eric Hobsbawm and Terence Ranger, 43 - 100. Cambridge: Cambridge University Press, 1983.

Day, David. ññThe Time for union is Come.ò̀ From Claiming a Continent: A New History of Australia, 193-208. Sydney and London, 1997.

Gibbs, Sir Philip. George the Faithful: The Life and Times of George V "The People's King," 1865-1936. London: Hutchinson \& Co. Ltd., 1936.

Gore, John. King George V: A Personal Memoir. London: Allermarle Library, 1949. Reprint.

Jordan, Bee, and John Van der Kiste. Dearest Affie, Alfred, Duke of Edinburgh, Queen Victoria's second son, 1844-1900. Foreword by Theo Aronson. Gloucester: Alan Sutton, 1984.

Kelly, Kristine. ñSpeaking Up: Caroline Christholmôs Rhetoric of Emigration Reform.ò Nineteenth Century Studies 23 (May 2009): 17-35.

Martin, Ged. Australia New Zealand and Federation, 1883-1901. London: Menzies Centre for Australian Studies, Kingô College London, 2001.

McCreery, Cindy. ñTelling the Story: HMS GalateaQ̂ Voyage to South Africa, 1867.ò South African Historical Journal 61, no.4 (2009): 817-837.

McKenna, Mark. The Captive Republic: A History of Republicanism in Australia 1788-1996. Cambridge: Cambridge University Press, 1996.

McKenna, Mark. ñMonarchy: From Reverence to Indifference.òIn Australia's Empire, edited by Deryck M. Schreuder and Stuart Ward, 261-187. Oxford: Oxford University Press, 2008.

Monaghan, Jay. Australians and the Gold Rush: California and Down Under, 1849-1854. Berkeley: University of California Press, 1966.

Murphy, Paul Thomas. Shooting Victoria: Madness, Mayhem, and the Rebirth of the British Monarchy. New York: Pegasus Books, 2012.

Richards, Eric. ñHow Did Poor People Emigrate form the British Isles to Australia in the Nineteenth Century.òJournal of British Studies 32, no.2 (July 1993): 250-279. 
Roberts, Andrew. ñGeorge V.òIn The Lives of the Kings \& Queens of England, edited by Antonia Fraser, 330-339. London: Seven Dials, 1999.

ñThe Trial of Henry James Oâfarrell for the Attempted Murder of His Royal Highness Alfred Ernest Albert, Duke of Edinburgh.ò Sydney: Illustrated Sydney News, 20 April 1868 Trove: Illustrated Sydney News. http://trove.nla.gov.au/version/31304072

Ward, Russell. ñDiggers, Democracy and Urbanisation c.1851-85.òIn Australia since the coming of man, 100-131. New York: St. Martinôs, 1987.

Wentworth, William Charles. Australasia (1823). Quoted in Russell Ward, 199. ñDiggers, Democracy and Urbanisation c.1851-85.òIn Australia since the coming of man, 100-131. New York: St. Martinôs, 1987. 